JOSING: Journal of Nursing and Health

Volume 1, Nomor 2, Juni 2021

e-ISSN: 2745-7877

p-ISSN: 2746-0851

DOI: https://doi.org/10.31539/josing.v1i2.2324

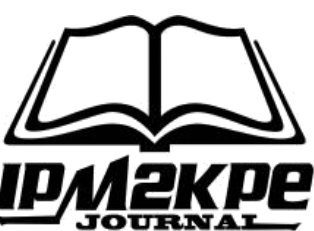

\title{
GUIDED IMAGERY TECHNIQUE IMPLEMENTATION REDUCING PRIMIGRAVIDA PREGNANCY ANXIETY BEFORE CHILDBIRTH DELIVERY
}

\author{
Yessi Andriani ${ }^{1}$, Endra Amalia ${ }^{2}$, Def Primal ${ }^{3}$ \\ Indonesian Pioneer University ${ }^{1,2,3}$ \\ def.primal.anatomy@gmail.com ${ }^{3}$
}

\begin{abstract}
This study aims to determine the application of nursing care to primigravida mothers in the face of childbirth using guided imagery techniques. This research method is case study research. The results of this study indicate that there is a decrease in the level of anxiety in patients after using guided imagery techniques for 3 meetings. In conclusion, interventions from journals related to nursing care for primigravida mothers who experience anxiety have been carried out well.
\end{abstract}

Keywords: Anxiety, Guided Imagery, Primigravida Pregnancy

\section{INTRODUCTION}

Based on the International Federation of Gynecologic Obstetrics, pregnancy is defined as fertilization or fusion of spermatozoa and ovum cells and is followed by cultivation or implantation to the womb (Yanti, 2015). During pregnancy, changes occur to mothers, both physically and psychologically. In general, physical changes during pregnancy are menstruation, enlarged breasts tissue, changes in the shape of the uterus, changes in the work system of the body organs, enlargement of the stomach, weight gain, weakening of the relaxation of the digestive tract muscles, sensitivity to sensation, and enlarged legs and arms (Zamriati, 2013). The psychological changes in the mother's third trimester are changes in the mother's psychology that seem more complex and increase again compared to the previous trimester, and this is due to the growing condition of the pregnancy (Zamriati, 2013).

Anxiety or anxiety is the most common psychiatric condition found throughout the world. According to Alza \& Ismarwati (2018) anxiety in pregnancy is an emotional reaction that occurs in pregnant women related to the concern of mothers with the welfare of themselves and their fetuses, the continuation of pregnancy, childbirth, the period after childbirth and when they have become a mother. Anxiety can be overcome in pharmacological and non-pharmacological ways.

Guided imagery or observed imagination technique is the development of mental functions that express oneself dynamically through a psychophysiological process involving all senses and bringing about changes in behavior, perception, or physiological responses with someone's guidance or through the media (Nurgiwiati, 2015). Based on the results of research conducted by Wulandari et al., (2019) shows that guided imagery can reduce anxiety levels before childbirth in third-trimester pregnant women. This can happen because guided imagery teaches to focus on positive imagination which can cause a relaxed state. 
Based on an interview conducted on the recruited patient (Mrs. T), which is one of the third-trimester primigravida pregnant women in the Lampasi Public Health Services, in Payakumbuh, obtained data that the patient is currently feeling anxious, worried, and afraid about the labor process that will be coming through. This could happen relating to her first pregnancy experience, having a lack of childbirth knowledge or awareness, and then stimulated from some stories or experiences her neighbor or people around. She explained that she has never received a scientific explanation from the midwife or nurses about how to deal with her anxiety. The better way to prevent this condition is a guided imagery technique (observed imagination technique). The purpose of this scientific case study is to be able to apply nursing care using guided imagery techniques in reducing the anxiety of primigravida mothers before their labor process in Lampasi Public Health Center.

\section{RESEARCH METHODS}

This scientific case study approach determined the reduction of prenatal pain intensity on mother's first pregnancy guided imagery therapy technique. We recruited a pregnant women in her first pregnancy after she reached the third semester period. To obtain the research result, we analized guided imagery therapy standard procedures from The National Safety Council (2004). We committed to exercise respondent on this technique for 3 times a day for 7 days therapy. This therapy duration consumed 15 menites period and we observed the guided imagery procedures before and after therapy's intervention (pre-post observations). Furthermore, we analized HARS (Hamilton Rating Scale for Anxiety) questionairs to measured the anxiety quality (without anxiety to severe level).

\section{RESULTS}

Guided imagery therapy proposes to reduce anxiety was done to the patient can be handled well. Evidenced by a decrease in the level of anxiety to the patient. Every time guided imagery therapy is performed. At the time of the first visit on March 12, 2021, the HARS scale was 21 (moderate anxiety). On the second visit on March 17, 2021, the HARS scale was 19 (mild anxiety). Meanwhile, on the third visit on March 19, 2021, a HARS scale of 15 (mild anxiety) was obtained.

\section{Pregnancy}

Pregnancy is a period from conception to birth of the fetus. The normal duration of pregnancy is 280 days ( 40 weeks or 9 months 7 days). This pregnancy is divided into 3 semesters, namely first-trimester pregnancy from 0-14 weeks, second-trimester pregnancy from 14-28 weeks, and third-trimester pregnancy from 28-42.

\section{Childbirth Delivery}

Childbirth is the process of releasing the products of conception (fetus and placenta) that have been terminated or can live outside the womb through the birth canal or other means, with assistance or without assistance (own strength). This process begins with true labor contractions, which are marked by progressive cervical changes and ends with the birth of the placenta. 


\section{Anxiety}

At the gestational age of seven months and over, the level of anxiety of pregnant women is getting more acute and intense as the birth of her first baby approaches. The existence of thoughts such as childbirth which will always be followed by pain will then cause an increase in the work of the sympathetic nervous system. An increase in the hormones adrenaline and noradrenaline or epinephrine and norepinephrine causes disregulation of the body's biochemistry, resulting in physical tension in pregnant women.

\section{Guided Imagery}

Guided imagery is one method that can be used to reduce anxiety by imagining a state or series of pleasant experiences in a guided manner by involving the senses. To maintain health or relaxation, can accelerate effective healing, reduce stress levels, and explore the experience of depression clients are the important things of this treatment. Guided Imagery therapy aims to reduce stress, reducing pain, difficulty sleeping, allergies or asthma, dizziness or migraines, and hypertension.

\section{Theoretical Nursing Care}

Assessment is the initial stage of the nursing process and is a systematic process and collection of data from various data sources to identify and evaluate the patient's health status, this data includes a medical history and physical examination. Later on, a nursing diagnosis is a clinical assessment of the client's response to health problems or life processes they are experiencing, both actual and potential. Moreover, nursing interventions are all treatments carried out by nurses based on clinical knowledge and assessment to achieve the expected outcome.

\section{Nursing Care in the Case Study Revealed}

The patient comes from Payakumbuh. At the time of the assessment on March 12, 2021, the client said that he was currently pregnant with his first child (G1P0A0) with 28 weeks of gestation and HPHT on August 1, 2020. The client said he was worried before giving birth because this was the client's first child and based on stories from the experiences of his neighbors. Clients say they often imagine negative things about their labor later. The client said it was difficult to sleep and lack rest and was easy to wake up. The client said that at night he could only sleep \pm 4 hours and during the day he could not sleep. The client said that he did not know how to deal with the feelings of anxiety he was experiencing at this time.

\section{DISCUSSIONS \\ Pregnancy}

Pregnancy is a period from conception to birth of the fetus. The normal duration of pregnancy is 280 days ( 40 weeks or 9 months 7 days). This pregnancy is divided into 3 semesters, namely first-trimester pregnancy from 0-14 weeks, second-trimester pregnancy from 14-28 weeks, and third-trimester pregnancy from 28-42 weeks (Aspiani, 2017). According to Widatiningsih \& Christin (2017) pregnancy is divided into first-trimester pregnancy (1-12 weeks), second-trimester pregnancy (13-27 weeks), and third-trimester pregnancy (28-40 weeks).

The meeting of male sperm cells and mature ovum cells from women and then fertilization occurs, this process starts a pregnancy. For a pregnancy to occur, there must be sperm, ovum, fertilization of the ovum (conception), implantation (oxidation), 
namely the attachment of the embryo to the uterine wall, to placentation/formation of the placenta. In the process of fertilization, two important elements that must be present are egg cells and sperm cells. An egg cell is produced by a woman's ovaries or ovaries, when ovulation occurs, a woman every month releases a mature egg, which is then caught by the frills (microfilaments fimbria) brought into the collar through the fallopian tubes (fallopian tubes), these cells can survive 12-48 hours after ovulation. In contrast to women who release one egg every month, the male hormone testes can continue to work to produce sperm. During coitus (coitus), millions of sperm cells (spermatozoon) enter the uterine cavity through the fallopian tubes to find an egg to be fertilized and in the end, only one of the best sperm cells can fertilize an egg.

According to Widatiningsih \& Christin (2017) signs of pregnancy are divided into three, namely a presumptive sign, a probable sign, and a positive sign. Psychological changes during pregnancy can be divided into 3 parts based on the pregnancy trimester pregnant women get through. Trimester I (Period of adjustment to pregnancy), there are often ambivalent feelings where pregnant women feel doubt about the fact that they are pregnant. Ambivalence can occur even when this pregnancy is planned and highly desirable. The response to this ambivalence describes that during the first few weeks of pregnancy, whether the mother is pregnant or not and spends a lot of time proving pregnancy (Widatiningsih \& Christin, 2017). The second trimester (healthy period) contributes to the mother feels more stable, the ability to self-regulate is better, the mother's condition is more pleasant, the mother is getting used to the physical changes in her body, the fetus is not too big so it doesn't cause any discomfort. And the third trimester (period of waiting and alert), the mother feels impatient waiting for the birth of her baby. Sometimes the mother is worried that her baby will be born at any time, this causes the mother to increase her awareness of the signs and symptoms of labor. The response to changes in self-image is that the mother feels strange and ugly (Widatiningsih \& Christin, 2017). According to Walyani (2015), the needs of pregnant women are nutrition, oxygen, clothing, elimination, mobilization, body mechanics, exercise, immunization, traveling, sexuality, and sleep rest.

\section{Childbirth Delivery}

Childbirth is the process of releasing the products of conception (fetus and placenta) that have been terminated or can live outside the womb through the birth canal or other means, with assistance or without assistance (own strength). This process begins with true labor contractions, which are marked by progressive cervical changes and ends with the birth of the placenta (Sholichah \& Lestari, 2017). Types of labor can be characterized by spontaneous labor, artificial delivery, and recommended delivery. And soon, it will perform the signs of labor processes beginning from the presence of uterine contractions, discharge mixed with blood, amniotic discharge, and cervical opening. It will be divided into some stages, are; stage I (opening), stage II (expulsion of the fetus), stage III (time for removal and expulsion of the placenta), and stage IV (observation).

\section{Anxiety}

Anxiety according to Yusuf (2015) is a vague feeling of discomfort or fear which is accompanied by a response (the cause is not specific or unknown to the individual). According to Yusuf (2015) anxiety or anxiety can be divided into the following response ranges: Mild anxiety, moderate anxiety, severe anxiety, and panic level 
anxiety. On Hamilton in Schlaepfer (2014) anxiety can be measured using a measuring instrument called the HARS (Hamilton Anxiety Rating Scale). This scale is a measure of anxiety that is based on the appearance of symptoms in individual experiencing anxiety. According to the HARS scale, 14 symptoms appear in individuals experiencing anxiety.

At the gestational age of seven months and over, the level of anxiety of pregnant women is getting more acute and intense as the birth of her first baby approaches. The existence of thoughts such as childbirth which will always be followed by pain will then cause an increase in the work of the sympathetic nervous system. An increase in the hormones adrenaline and noradrenaline or epinephrine and norepinephrine causes disregulation of the body's biochemistry, resulting in physical tension in pregnant women. The impact of this physiological process can arise on everyday behavior. Pregnant women become irritable or irritated, are anxious, unable to focus, hesitate, even possibly want to run away from the realities of life (Janiwaty \& Pieter, 2013).

\section{Guided Imagery}

Guided imagery is one method that can be used to reduce anxiety by imagining a state or series of pleasant experiences in a guided manner by involving the senses (Purnama, 2016). To maintain health or relaxation, can accelerate effective healing, reduce stress levels, and explore the experience of depression clients are the important things of this treatment. Guided Imagery therapy aims to reduce stress, reducing pain, difficulty sleeping, allergies or asthma, dizziness or migraines, and hypertension. The techniques should be implemented in these treatments including guided walking imagery, autogenic abstraction, covert sensitization, and covert behavior rehearsal.

Indications for this treatment are all clients who have negative thoughts or deviant thoughts that interfere with behavior (maladaptive) such as overgeneralization, mental filters, stress, anxiety, depression, hypochondria pain.

\section{Theoretical Nursing Care}

Assessment is the initial stage of the nursing process and is a systematic process and collection of data from various data sources to identify and evaluate the patient's health status, this data includes a medical history and physical examination. Later on, a nursing diagnosis is a clinical assessment of the client's response to health problems or life processes they are experiencing, both actual and potential. Moreover, nursing interventions are all treatments carried out by nurses based on clinical knowledge and assessment to achieve the expected outcome. Meanwhile, nursing actions are specific behaviors or activities performed by nurses to implement nursing interventions. Actions in nursing interventions consist of observation, therapeutic, education, and collaboration (PPNI, 2018).

Furthermore, implementation is an action that has been planned in nursing plans. Actions include both independent action and collaborative action (Tarwoto \& Wartonah, 2015). What we revealed in our previous study, hypnobirthing significantly reduce pain quality for mothers in labor process. Consistently, we can say that pain management could be intervented by obtaining hypnobirting and guided imagery therapy (Andriani et al, 2020). Finally, nursing evaluation is the final stage of a series of nursing processes to achieve the goals of nursing actions that have been carried out or need another approach. 


\section{Nursing Care in the Case Study Revealed}

The patient comes from Payakumbuh. At the time of the assessment on March 12, 2021, the client said that he was currently pregnant with his first child (G1P0A0) with 28 weeks of gestation and HPHT on August 1, 2020. The client said he was worried before giving birth because this was the client's first child and based on stories from the experiences of his neighbors. Clients say they often imagine negative things about their labor later. The client said it was difficult to sleep and lack rest and was easy to wake up. The client said that at night he could only sleep \pm 4 hours and during the day he could not sleep. The client said that he did not know how to deal with the feelings of anxiety he was experiencing at this time. The nursing diagnosis found in Mrs. $\mathrm{T}$ is anxiety related to lack of exposure to information as evidenced by the client feeling worried about the delivery process later, sleep disturbance related to environmental barriers, evidenced by the client complaining of difficulty sleeping and often being awake during sleep and knowledge deficits about anxiety associated with less exposure to information proven by the client asking the problem it faces.

The intervention carried out on Mrs. T for the first diagnosis is to do guided imagery techniques. The second diagnosis is to provide sleep support. Meanwhile, the third diagnosis is to provide health education. After the action plan is compiled, the next implementation of nursing care is following the plan that has been compiled. In implementing the implementation, the nurse can make observations or can discuss with clients or families the actions we will take. Nursing implementation is carried out for 3 meetings.

Evaluation of nursing actions that have been done. Of the three nursing diagnoses that have been enforced and the implementation that has been carried out under the nursing action plan, the results are included in the evaluation as follows: a decrease in the level of anxiety in Mrs. After doing guided imagery therapy, there was a change in sleep patterns felt by clients after being given sleep support implementation and an increase in Mrs. T about anxiety and how to reduce it.

\section{Nursing Analysis with KKMP Concepts to Case Concepts}

Nursing care for the patient is done by applying guided imagery techniques to reduce anxiety in the face of childbirth carried out from 12-19 March 2021. The first nursing problem that is obtained is anxiety related to the lack of exposure to information as evidenced by the client feeling worried about the labor process later. Based on the results of Mukhadiono et al., (2015) study, the anxiety level of primigravida mothers in facing childbirth for the first time was higher than in women who were pregnant for the second time. Anxiety during pregnancy and stress-related hormonal changes from mid to late pregnancy is associated with the mother's moodiness, restlessness, and anxiety.

The second nursing problem that is found is sleep pattern disturbances related to environmental barriers as evidenced by clients complaining of difficulty sleeping and often being awake during sleep. In the results of Field's research, it is said that pregnant women who experience stress also experience insomnia so that which can increase blood pressure, can increase maternal blood pressure, increase the risk of premature pregnancy, and even miscarriage.

The third nursing problem that is obtained is a deficit of knowledge about anxiety related to the lack of exposure to information as evidenced by the client asking the problem he is facing. Knowledge deficit is the absence or lack of cognitive information related to certain topics by not showing responses, changes, or patterns of human 
dysfunction, but rather as an etiology or supporting factors that can add to a variety of responses (PPNI, 2018). The last common problem that pregnant women would not consider about is their methabolic health status, especially their tendencies to have diabetes while pregnancy.

We can assume that pregnant women who have the higest level of stress and anciety related to their fhysiological and psychological changes while in pregnant condition, increase their consumption of fast-processed foods. This condition automatically increases their carbohydrate intake which leading to the risk factor for gestational diabetes mellitus (GDM) incidence (Primal, et al, 2021).

\section{Analysis of Innovated Interventions with Concepts and Related Research}

After getting three nursing problems in the case review, one of the interventions the author made was related to the main nursing problem, namely guided imagery therapy. Guided imagery is a method that can be used to reduce anxiety by imagining a situation or a series of pleasant experiences in a guided manner by involving the senses (Purnama, 2016). This is in line with the research conducted by Priharyanti et al., (2019) regarding the effect of guided imagery therapy on reducing the anxiety level of third-trimester pregnant women in the work area of Mijen Public Health Center, Semarang City. The results obtained with a P-value of 0.000 , meaning that there is an effect of guided imagery therapy on reducing the anxiety level of third-trimester pregnant women. The results of the statistical test P-value 0,000 mean that there is a significant effect between guided imagery therapy on reducing the anxiety level of third-trimester pregnant women in the work area of Mijen Public Health Center, Semarang City in 2019. This can happen because guided imagery teaches to focus on positive imagination which can cause relaxing situation.

\section{CONCLUSION}

From the nursing care that has been carried out on Mrs. With the application of guided imagery therapy, it can be concluded that the level of anxiety in the patient decreased after the intervention. Furtheremore, guided imagery therapy is effectively proposed to be recent and updated in nursing intervention periodically especially in prenatal pain therapy.

\section{ACKNOWLEDGMENT}

Finally, health care institution could benefit the nurses competencies with this therapy's clinical workshops and skills program.

\section{REFERENCES}

Alza, N., \& Ismarwati, I. (2018). Faktor-Faktor yang Mempengaruhi Kecemasan Ibu Hamil Trimester III. Jurnal Kebidanan dan Keperawatan Aisyiyah, 13(1), 1-6. https://doi.org/10.31101/jkk.205

Andriani, Y., Primal, D., \& Delima, M. (2020). Hypnobirthing Pain Management for Maternal Pain Adaptation along Labor Process. JOSING: Journal of Nursing and Health, 1(1), 18-25. https://doi.org/https://doi.org/10.31539/josing.v1i1.1165

Aspiani, R. Y. (2017). Buku Ajar Asuhan Keperawatan Maternitas. Jakarta: Trans Info Media

Janiwarty, B \& Pieter, H. Z. (2013). Pendidikan Psikologi untuk Bidan Suatu Teori dan Terapannya, Yogyakarta: Rapha Publishing 
Mukhadiono, M., Subagyo, W., \& Dyah, W. (2015). Hubungan antara Dukungan Suami dengan Tingkat Kecemasan pada Ibu Hamil Primigravida Trisemester III dalam Menghadapi Persalinan. Jurnal Keperawatan Soedirman, 10 (1). 53-59. http://jks.fikes.unsoed.ac.id/index.php/jks/article/view/592/0

Nurgiwiati, E. (2015). Terapi Alternatif \& Komplementer dalam Bidang Keperawatan. Bogor : In Media

PPNI, T. P. (2018). Standar Intervensi Keperawatan Indonesia (SIKI): Definisi dan Tindakan Keperawatan ((cetakan II) 1 ed.). Jakarta: DPP PPNI

Priharyanti, W.,Retnaningsih, D., \& Aliyah, E. (2019). Pengaruh Prenatal Yoga Terhadap Tingkat Kecemasan pada Ibu Primigravida Trimester II dan III di Studio Qita Yoga Kecamatan Semarang Selatan Indonesia. Journal Keperawatan, 9(1), 25-34. http://ejournal.umm.ac.id/index.php/keperawatan/issue/view

Primal, D., Putri, T., \& Meiriza, W. (2021). Asupan Karbohidrat Harian terhadap Risiko Kejadian Diabetes Melitus Gestasi (GDM) melalui Glyco-Hemoglobin Ibu Hamil. Jurnal Keperawatan Silampari, 4(2), 510-518. https://doi.org/https://doi.org/10.31539/jks.v4i2.1876

Purnama, B. W. H. (2016). Guided Imagery terhadap Tingkat Kecemasan Menjelang Persalinan pada Ibu Hamil. Jurnal Ilmiah Psikologi Terapan, 3(2), 287-307. https://ejournal.umm.ac.id/index.php/jipt/article/view/3533

Schlaepfer, T. E., Bewernick, B. H., Kayser, S., Hurlemann, R., \& Coenen, V. A. (2014). Deep Brain Stimulation of the Human Reward System for Major Depression-Rationale, Outcomes and Outlook. Neuropsychopharmacology, 39(6), 1303-1314. DOI: $10.1038 / n p p .2014 .28$

Sholichah, N., \& Lestari, N. P. (2017). Asuhan Kebidanan Komprehensif Pada Ny. Y (Hamil, Bersalin, Nifas, BBL dan KB), Jurnal Komunikasi Kesehatan, VIII(1), 79-95. https://e-journal.akbid-purworejo.ac.id/index.php/jkk14/article/view/132

Tarwoto, T., \& Wartonah, W. (2015). Kebutuhan Dasar Manusia dan Proses Keperawatan Edisi 5. Jakarta Selatan: Penerbit Salemba Medika

Walyani, E. S. (2015). Asuhan Kebidanan pada Kehamilan. Yogyakarta: Pustaka Barupess

Widatiningsih, S. \& Christin, H. T. D. (2017). Praktik Terbaik Asuhan Kehamilan. Yogyakarta: Transmedika

Wulandari, P., Sofitamia, A., \& Kustriyani, M. (2019). The Effect of Guided Imagery to The Level of Anxiety of Trimester III Pregnant Woman in The Working Area of Mijen Health Center in Semarang City. Media Keperawatan Indonesia, 2(1), 29. https://doi.org/10.26714/mki.2.1.2019.29-37

Yanti, Y. E. 2015. Hubungan Pengetahuan Ibu dan Dukungan Suami pada Ibu Hamil terhadap Keteraturan Kunjungan Antenatal Care (ANC) di Puskesmas Wates Lampung Tengah Tahun 2015. Jurnal Kebidanan, 1(2), 81-90. http://ejurnalmalahayati.ac.id/index.php/kebidanan/article/view/550

Yusuf, A. H., Fitryasari, R., \& Nihayati, N. E. (2015). Buku Ajar Keperawatan Kesehatan Jiwa. Jakarta: Salemba Medika

Zamriati, W., Hutagaol, E., \& Wowiling, F. (2013). Faktor-Faktor yang Berhubungan dengan Kecemasan Ibu Hamil Menjelang Persalinan di Poli Kia PKM Tuminting. $\begin{array}{llll}\text { Jurnal Keperawatan Unsrat, } & 109817 .\end{array}$ https://ejournal.unsrat.ac.id/index.php/jkp/article/view/2249 